\title{
Development of a laboratory scale continuous dry stirred media mill
}

ÁDÁM RÁCZ - University of Miskolc, Institute of Raw Material Preparation and Environmental Processing LÁszLó TAMÁS - University of Miskolc, Institute of Raw Material Preparation and Environmental Processing Érkezett: 2019. 04. 07. - Received: 07. 04. 2019. - https://doi.org/10.14382/epitoanyag-jsbcm.2019.17

\section{Abstract}

Stirred media mills are widely operated in the industry for the production of fine ground materials. The application of the mill type in dry mode came to the front in the recent years. Most of the operating dry mills have vertical orientation, however the horizontal type mills are also available on the market now, and some research is still ongoing for the development of this mill type. In the present study two development phase of a laboratory scale continuous dry, horizontal stirred media mill is presented. In the first phase the working principle of the mill, the air flow rate and feed rate were investigated. Later based on the operational experience and earlier results of the grinding experiments the mill has undergone significant changes resulted in a significant increase in the amount of air flow rate through the mill. The measurement results of the second phase led to that the mill has a significantly higher air flow rate and stable constant feed rate, however the control of the air flow during operation is essential to achieve the required product particle size.

Keywords: dry fine grinding, stirred media mill, continuous operation

Kulcsszavak: száraz finomôrlés, keverômalom, folyamatos üzem

\section{Introduction}

Dry stirred media milling is a highly energy-efficient and promising technology that can be used to produce fine submicron ground materials, but there are still many problems to be solved in this area for wider industrial application. The operation of a horizontal dry stirred media mill was investigated by [1], found that increase of the stirrer speed produced finer material up to a point that further addition of energy was converted into heat causing decreased efficiency of the grinding operation, lower media fillings created inefficient grinding environments. Later in the same mill, the effects of chamber diameter and stirrer design on dry horizontal stirred mill performance was investigated [2], found that the larger gap between the stirrer edge and mill chamber performed more efficient grinding operation. Stirrer design tests were conducted with cross, wing and disc designs having the same diameter. At higher energy levels $(>40 \mathrm{kWh} / \mathrm{t})$ wing and cross design stirrers utilize more energy than the disc design to achieve the same degree of size reduction. Reduced milling performance of the wing and cross designs were attributed to increased mill chamber temperature which indicated that most of the energy was dissipated as heat. Dry grinding experiments in a self-modified horizontal stirred media mill was presented by [3]. It was revealed that dry fine grinding in continuously operated horizontal stirred media mills is strongly determined by both, machine related values like the choice of process parameters as well as product related characteristics like the powder flow ability. They confirmed the existence of optimum stressing conditions at comparatively low stressing energies. High powder flow abilities constantly lead to lower grinding efficiencies in the present study. However, also very low powder flow abilities are identified to decrease the grinding efficiency, as it causes unfavourable stressing conditions and an inefficient grinding media motion. The stirrer tip speed was identified to be a more critical process parameter than other values like bead size and bead material, since the deflector wheel is coupled with the stirrer shaft, the stirrer tip speed does not only influence the stressing energy of the beads, but also the retention behaviour of the wheel classifier.

In the present article, the first two development phases of a laboratory scale continuous dry horizontal stirred media milling system are presented.

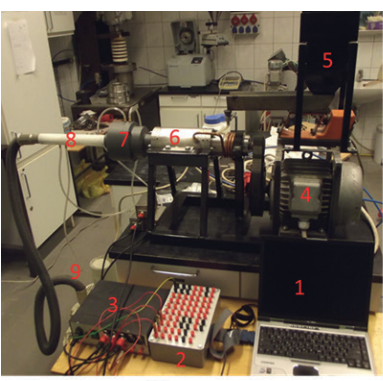

a)

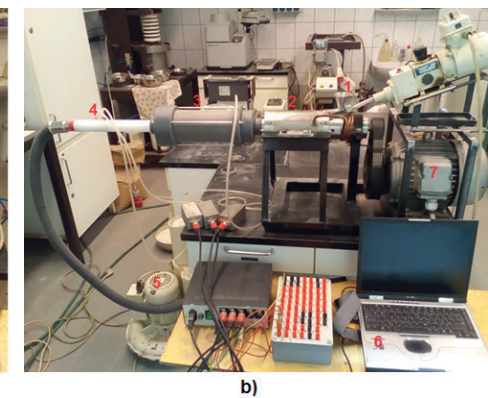

Fig. 1 Continuous dry stirred media mill - first (a) and second (b) configuration

1. ábra Folyamatos üzemü száraz keverömalom - az elsö (a) és második (b) konfiguráció

\section{Experimental}

A continuous dry stirred media mill was developed and built, where the solid material is transported in the mill by air flow. The effective volume of the mill is $520 \mathrm{~cm}^{3}$. The mill can be operated in open circuit mode. The stirred media mill is equipped with a six specially shaped triangle discs. The mill is double-walled to cool the grinding chamber. The operation of the motor and the ventilator is regulated by a frequency controller, so the rotor's revolutions per minute and circumferential speed could be adjusted. Parts of the milling system in the first configuration are as follows (Fig 1a): 1. Computer; 2. Electrical control board of the data acquisition 
system; 3. Power supply of the data acquisition system; 4. Mill engine; 5 . Silo and vibration feeder; 6 . Stirred media mill; 7. Filter; 8. Venturi tube; 9. Ventilator.

The parts of the second configuration are as follows (Fig 1b): 1. Screw feeder; 2. Stirred media mill; 3. Filter; 4. Venturi tube; 5. Fan; 6. Data acquisition system; 7. Mill engine. Online measurement and data acquisition system was developed for the grinding system. For the data acquisition a self-written LabWindows program is used. The measuring system is capable to measure the static pressure after the mill (p1), the static pressure after the filter (p2) and the pressure drop in the Venturi tube $(\Delta p)$. The velocity of the air in the Venturi tube is calculated from the pressure drop and therefore the volumetric flow rate of the air $(\mathrm{Q})$ can be determined as well.

$Q=A_{2} \sqrt{\frac{2}{\rho} \cdot \frac{\Delta p}{1-\left(\frac{A_{2}}{A_{1}}\right)^{2}}}$

During the experiments limestone was used as model material for the grinding. The limestone powder was obtained from the Felnémet mine site. The limestone powder first was sieved at $106 \mu \mathrm{m}$ by laboratory sieve and then the material was further separated in an air separator (type NETZSCH CFS 5 HD-S) to separate the most of the fine particles under $10 \mu \mathrm{m}$ and to receive an appropriate feed for the grinding experiments. Rotor speed of the classifier was set to 3500 RPM, and the air flow rate was $63 \mathrm{~m}^{3} / \mathrm{h}$.

The particle size distribution of the ground material was determined using a HORIBA LA-950V2 type laser particle size analyzer. From the measured data the computer calculated the particle size distribution according to the Mie-theory. During the measurement ultrasonic treatment was used for the dispersion of fine particles.

During the experiments with the first configuration $0.2,0.4$, 0.6 and $0.8 \mathrm{~kg} / \mathrm{h}$ feed rate was applied. The effect of the rotor velocity was investigated at $6,8,10$ and $11 \mathrm{~m} / \mathrm{s}$. To measure the effect of the air flow rate, the frequency of the ventilator rotor was moderated between 20 and $35 \mathrm{~Hz}$.

During the grinding experiments of the second configuration 0.8-1 and 1-1.2 mm zirconium silicate grinding media were used. The feed rate was constant during all grinding experiments $0.6 \mathrm{~kg} / \mathrm{h}$. Grinding media filling ratio was set to 0.6 . The exact air flow rates were measured during the experiments.

\section{Results}

The operation of the mill configuration "A" was investigated in several steps. First the fan operation was tested. It was found that the air flow through the mill increasing linearly by the frequency of the fan current in case of empty mill. Later the mill was filled with grinding media and the mill rotor at different velocities was operated (Fig. 2). The air flow rate was not affected by the rotor circumferential velocity, at a certain fan current frequency. After evaluating the pressure loss data, it became clear that the highest pressure loss is on the filter.

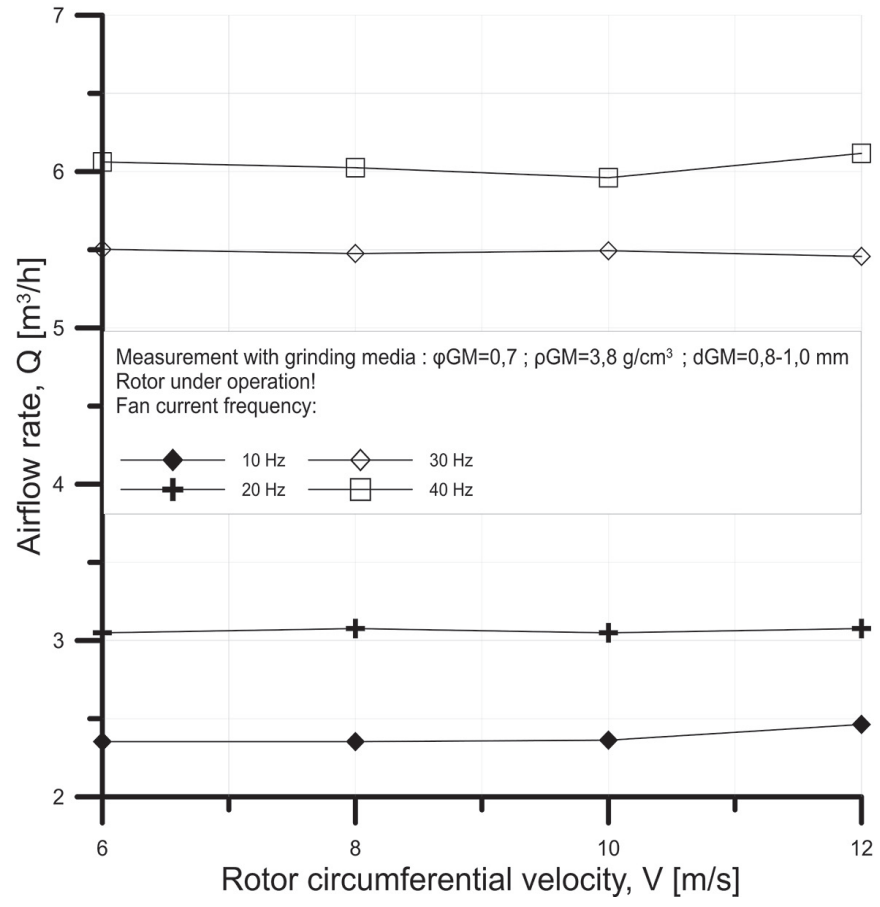

Fig. 2 Airflow rate at different rotor circumferential velocities

2. ábra Légáramok különbözö rotor kerületi sebességek mellett

During the milling experiments with the configuration A it could be observed that the airflow rate decreases as a function of the grinding time (Fig 3). During grinding the pressure loss on the filter increases with the material layer on the filter surface increases. As a result, the average internal air velocity in the grinding chamber decreases, and thus the amount of the transported material inside the mill decreases, which could lead to a blockage in the mill. To solve this problem, at longer grinding experiments the filter should have been cleared, and thus the pressure loss decreased, and the mill was able to operate stable again.

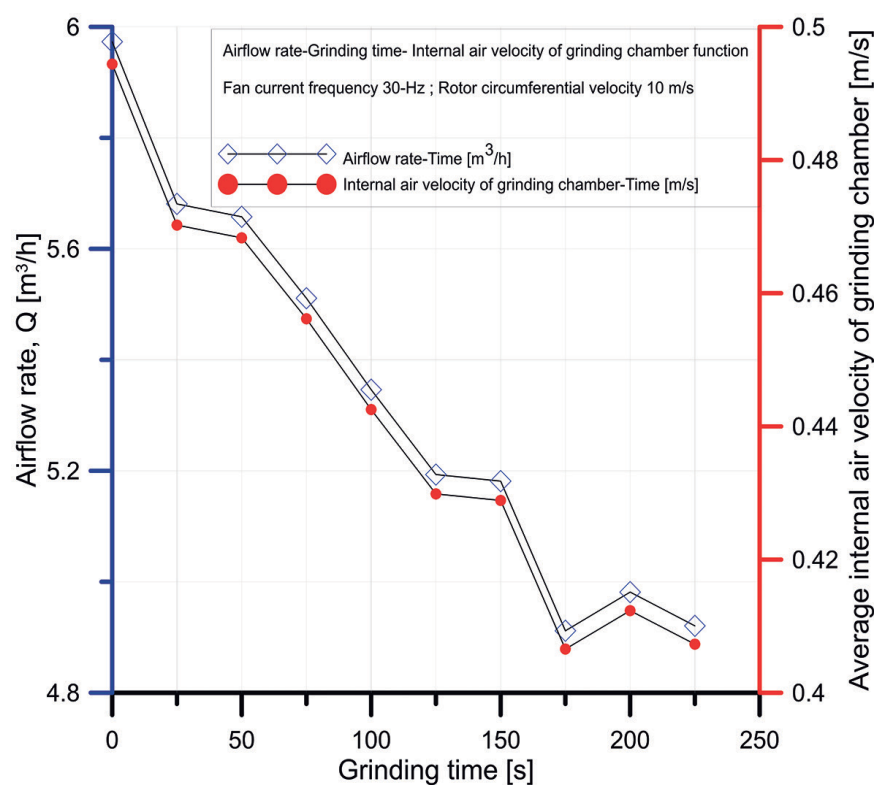

Fig. 3 Airflow rate and air velocity changes within the mill during grinding 3. ábra Légáram és légsebesség változás a malmon belül örlés közben 
After the first grinding experiments systematic grinding experiments were carried out with the construction $\mathrm{A}$ at different airflow and feed rates. The effect of the feed rate on the cumulative undersize of the product can be seen in Fig 4. In the feed material less than $3 \%$ are under $10 \mu \mathrm{m}$. After grinding at different feed rates the ratio of the fine $(<10 \mathrm{um})$ particle significantly grows up to $30 \%$. The finest product was achieved by the $0.2 \mathrm{~kg} / \mathrm{h}$ feed rate. Higher feed rates resulted in coarser product. From the cumulative undersize curves it can be seen that the maximal particle size of the feed did not decrease, so the stress energy inside the mill was not enough to the effective body breakage of the particles.

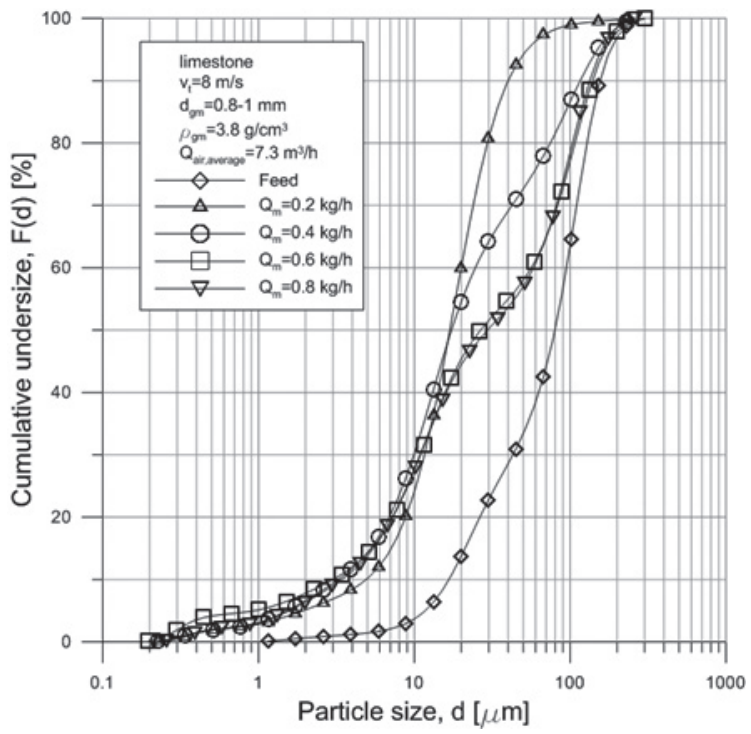

Fig. 4. Effect of the feed rate on the cumulative undersize of the product

4. ábra A feladási tömegáram hatása az örlemény szemcseméret-eloszlására

The effect of the feed rate on the median particle size at different air flow rates can be seen in Fig 5. At a certain air flow rate, the higher the feed rate, the higher the median particle size. At a certain feed rate the higher the air flow rate, the finer the product. The lowest median particle size was achieved at $0.2 \mathrm{~kg} / \mathrm{h}$ feed rate and $7.3 \mathrm{~m}^{3} / \mathrm{h}$ average air flow rate, its value was $16.8 \mu \mathrm{m}$. At low feed rates (low mill loading) increasing the air flow rate did not have significant effect on the median particle size, the grinding is sufficient, the ground material is fine. Increasing the feed rate, at same air flow rates, the product became coarser, because the residence time in these cases was determined by the quantity of feed rate. However, at the same feed rate, the higher air flow gives a finer product. The explanation for this is that the grinding efficiency was improved by increasing the air flow. The main limiting factor in the production of fine materials by dry grinding is the adhesion of the fine particles and the sticking of the particles on the mill liners and on the grinding beads, which decreases the efficiency of grinding. The higher air flow reduced these effects more sufficiently, so the product became finer [4].

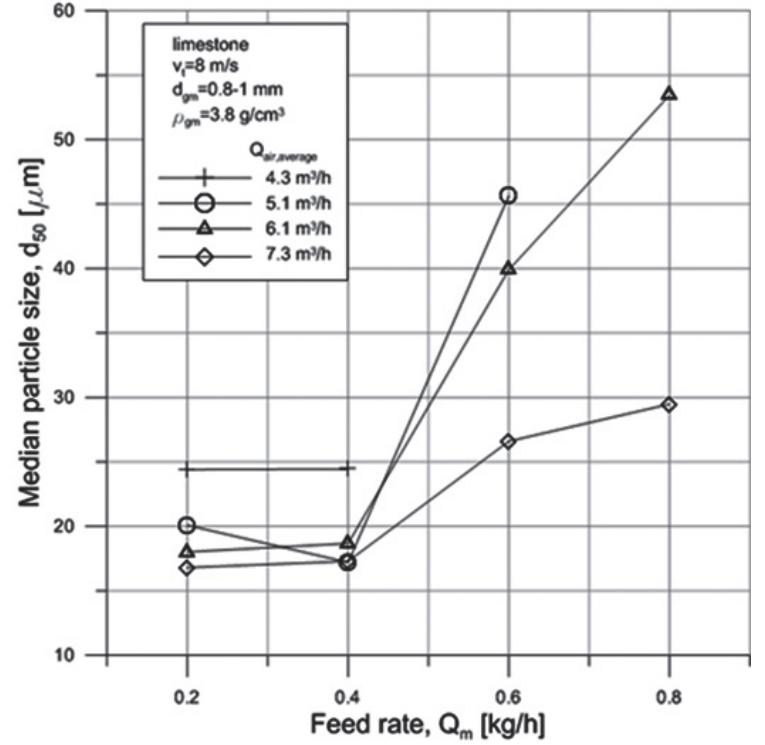

Fig. 5 Effect of the feed rate on the median particle size at different air flow rates

5. ábra A feladási tömegáram hatása a median szemcseméretre különbözö légáramok esetén

Based on the grinding results and the operational experiments problems of the first configuration came to the surface:

- Feeding of fine material couldn't be done, because of the feeding tubes' blockage, the continuous and constant feeding of the mill also was a problem because the air flow rate influenced the feed mass flow.

- The applied filter wasn't efficient enough, after a short period of time it had to be cleaned.

- The pressure drop of the mill and filter was too high, thus the energy consumption of ventilator was high.

From the grinding experiments with configuration $\mathrm{A}$ it can be stated that at the applied air flow rates the material transported not only by air, but by a simple flow through as well.

Based on the earlier grinding experiments and results the continuous dry stirred media milling system was undergone improvements that enable more efficient grinding and more reliable operation. For this reason, first of all, the feeding technique had to be changed, which in practice was realized in the form of a storage unit with a larger cone angle and a screw feeder placed beneath it. In addition to providing continuous and stable mass flow, it appears as a further advantage to completely separate the material feed and airflow. In this way, the material feed and the airflow rate became independent. To reduce the pressure loss on the filter, it was further changed to a bag type. The pressure loss of the mill was also decreased. Measurements made with the " $\mathrm{B}$ " mill construction, similarly to previous results, were carried out systematically, with preplanned steps, helping to improve the comparability of the data obtained from the measurements of the two different constructions. During the first measurement experiment, the operation of the newly built air filter system was tested, relying on data from the previous measurement results, with a feed rate of $0.6 \mathrm{~kg} / \mathrm{h}$. In the grinding experiments the mill was operated for 40 minutes and sampling and filter cleaning was carried 
out after every 10 minutes. The change of the air flow rate of such grinding experiment can be seen in Fig 6 . After each filter cleaning the starting air flow rate decreased. The level of the air flow rate however became significantly higher than in the case of construction A, so the pressure loss of the mill and filter was successfully decreased. The air flow rate linearly decreases as a function of the grinding time. The starting $26 \mathrm{~m}^{3} / \mathrm{h}$ air flow rate was decreased to $20 \mathrm{~m}^{3} / \mathrm{h}$ after 40 minutes operation.

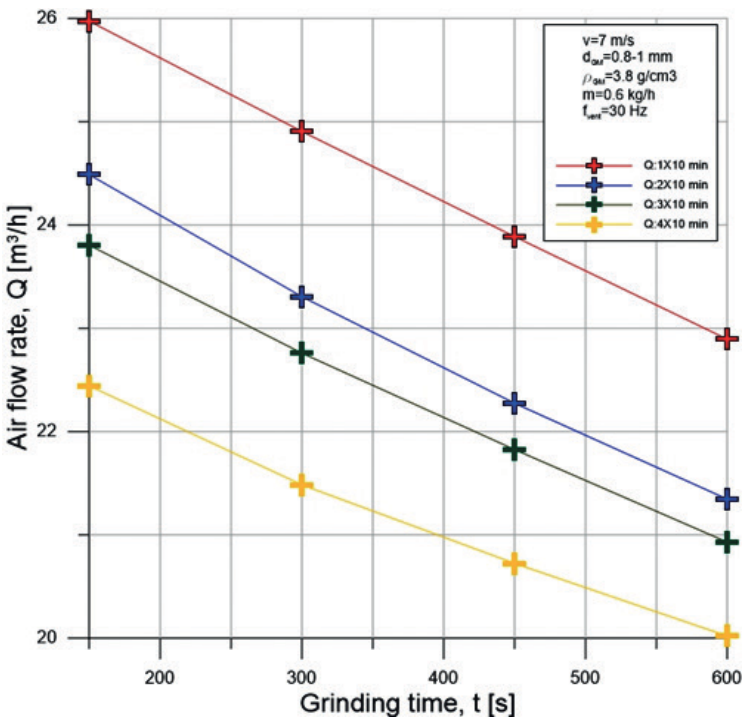

Fig. 6 Effect of operational time on the air flow rate

6. ábra Az üzemelési idő hatása a légáramra

The cumulative undersize of the ground material at $7 \mathrm{~m} / \mathrm{s}$ rotor velocity and after 40 min operation can be seen in Fig. 7. The product of the mill is finer than the feed, however the degree of the size reduction is relatively low. The significantly higher air flow rates decreased the residence time of the particles inside the mill, thus the stress number of the particles, so the grinding was not sufficient.

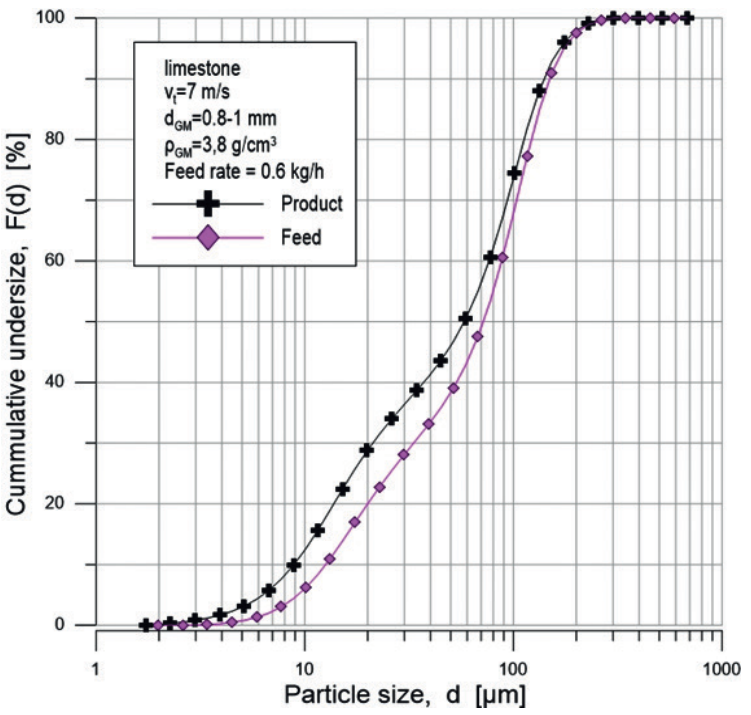

Fig. 7 Cumulative undersize of the product after grinding at $7 \mathrm{~m} / \mathrm{s}$ rotor velocity 7. ábra Azörlemény szemcseméret-eloszlása $7 \mathrm{~m} / \mathrm{s}$ rotor kerületi sebesség esetén

Increasing the stress energy by increasing the grinding media diameter to $1-1.2 \mathrm{~mm}$ and the rotor circumferential velocity to $10 \mathrm{~m} / \mathrm{s}$ did not resulted in finer product (Fig. 8). This can be explained by the centrifugal forces created by the higher rotor velocity. Possible way to increase the grinding efficiency is to significantly increase the size of the grinding beads and reduce the rotor velocity significantly. The larger grinding media results in lower pressure loss in the mill and higher pore volume which can help the transportation of the ground material inside the mill.

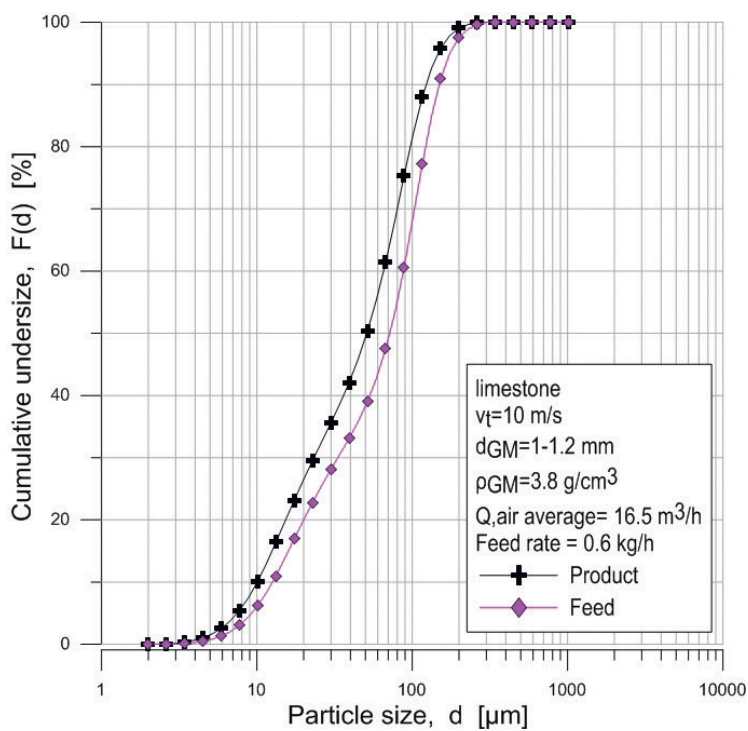

Fig. 8 Cumulative undersize of the product after grinding at $10 \mathrm{~m} / \mathrm{s}$ rotor velocit 8. ábra Az örlemény szemcseméret-eloszlása $10 \mathrm{~m} / \mathrm{s}$ rotor kerületi sebesség esetén

The effect of the air flow rate on the product fineness can be seen in Fig. 9. The higher ventilator current frequency resulted in higher average air flow rates. The higher the air flow rate, the finer the product. Higher air flow rate results in lower residence time in the mill; however the higher air flow rate helps to discharge the particles from the mill.

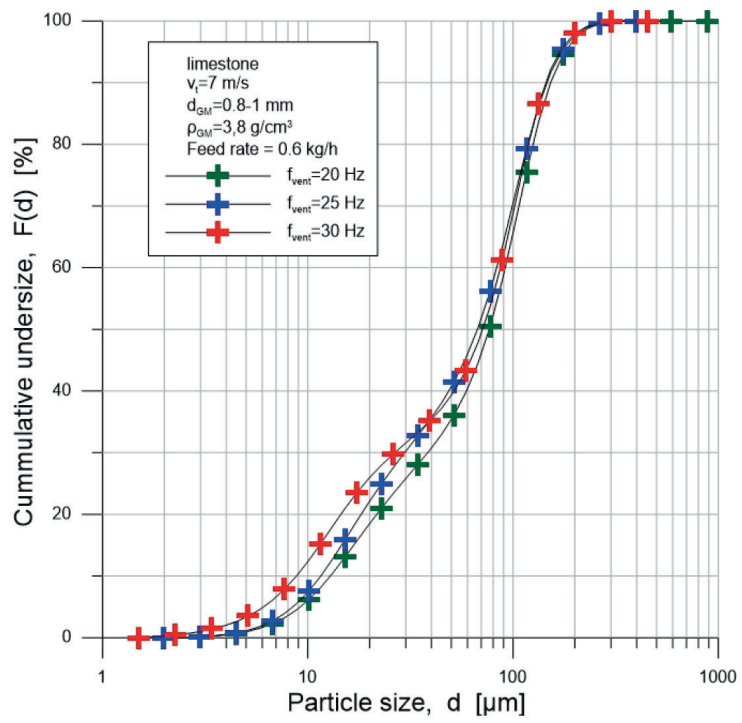

Fig. 9 Cumulative undersize curves of the ground material at different air flow rates 9. ábra Az örlemények szemcseméret-eloszlása különbözö légáramok esetén

This can be seen in Table 1, where the ratios of the product mass at different air flow rates are presented. The higher air 
flow rate is more effective to discharge the fine particle from the grinding chamber. At lower air flow rate possibly more fine particle was created because of the longer residence time, but with the lower air flow the product particle was not discharged from the mill sufficiently, so more and more fine particle remained in the grinding chamber, which could result the blockage of the mill at longer operational time.

\begin{tabular}{cc} 
Average air flow rate $\left[\mathrm{m}^{3} / \mathrm{h}\right]$ & Ratio of the product mass [\%] \\
\hline 24.2 & 86.3 \\
\hline 19.5 & 83.4 \\
\hline 16.8 & 79.3
\end{tabular}

Table 1 Ratio of the product mass at different air flow rates

1. táblázat A termék tömegének aránya különböző légáramok esetén

\section{Conclusions}

In the present study the first two development phase of a laboratory scale horizontal dry stirred media mill was presented. During the development the stable operational time of the mill was successfully extended, however further improvements are necessary for a long term operation of the milling system. The results proved that the mill can effectively produce particles below 10 microns, however the control of the product particle size requires constant air flow rate during grinding. To ensure this, the future goal is to build a controlling system for the fan, which can compensate the increase in pressure loss of the mill and filter during grinding.

\section{Acknowledgement}

The research work described in this article was supported by the European Union, as part of the project EFOP-3.6.116-2016-00011 "Youthful and Renewable University Innovative Knowledge City - the Institutional Development of the University of Miskolc for Intelligent Specialization". Co-financed by the European Social Fund. The research work was supported by the János Bolyai Research Scholarship of the Hungarian Academy of Sciences.

\section{References}

[1] O. Altun, H. Benzer, U. Enderle, Effects of operating parameters on the efficiency of dry stirred milling, Miner. Eng. 43-44 (2013) 58-66. https://doi.org/10.1016/j.mineng.2012.08.003.

[2] O. Altun, H. Benzer, U. Enderle, The effects of chamber diameter and stirrer design on dry horizontal stirred mill performance, Miner. Eng. 69 (2014) 24-28. https://doi.org/10.1016/j.mineng.2014.07.008

[3] P. Prziwara, S. Breitung-Faes, A. Kwade, Impact of the powder flow behavior on continuous fine grinding in dry operated stirred media mills, Miner. Eng. 128 (2018) 215-223. https://doi.org/10.1016/j.mineng.2018.08.032.

[4] Á. Rácz, L. Tamás, I. Gombkötő, B. Csőke, J. Faitli, Effect of the milling parameters on the product dispersity and energy consumption in a continuous dry air- transported stirred media mill, Proc. 15th Eur. Symp. Comminution Classif. (2017) 1-5.

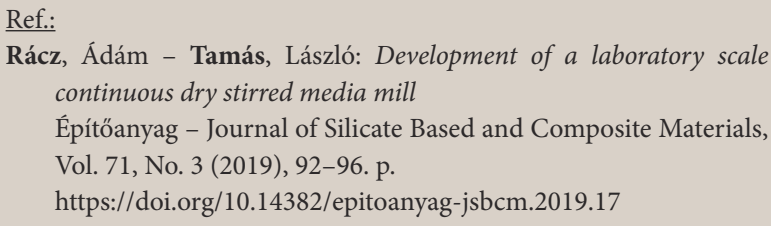

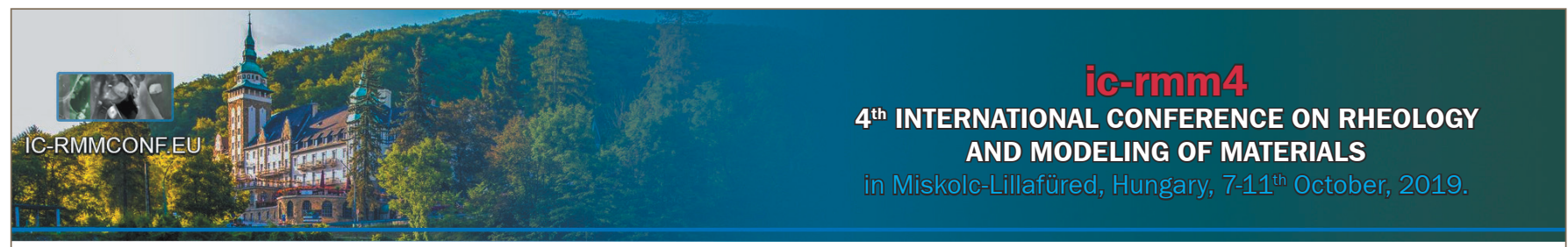

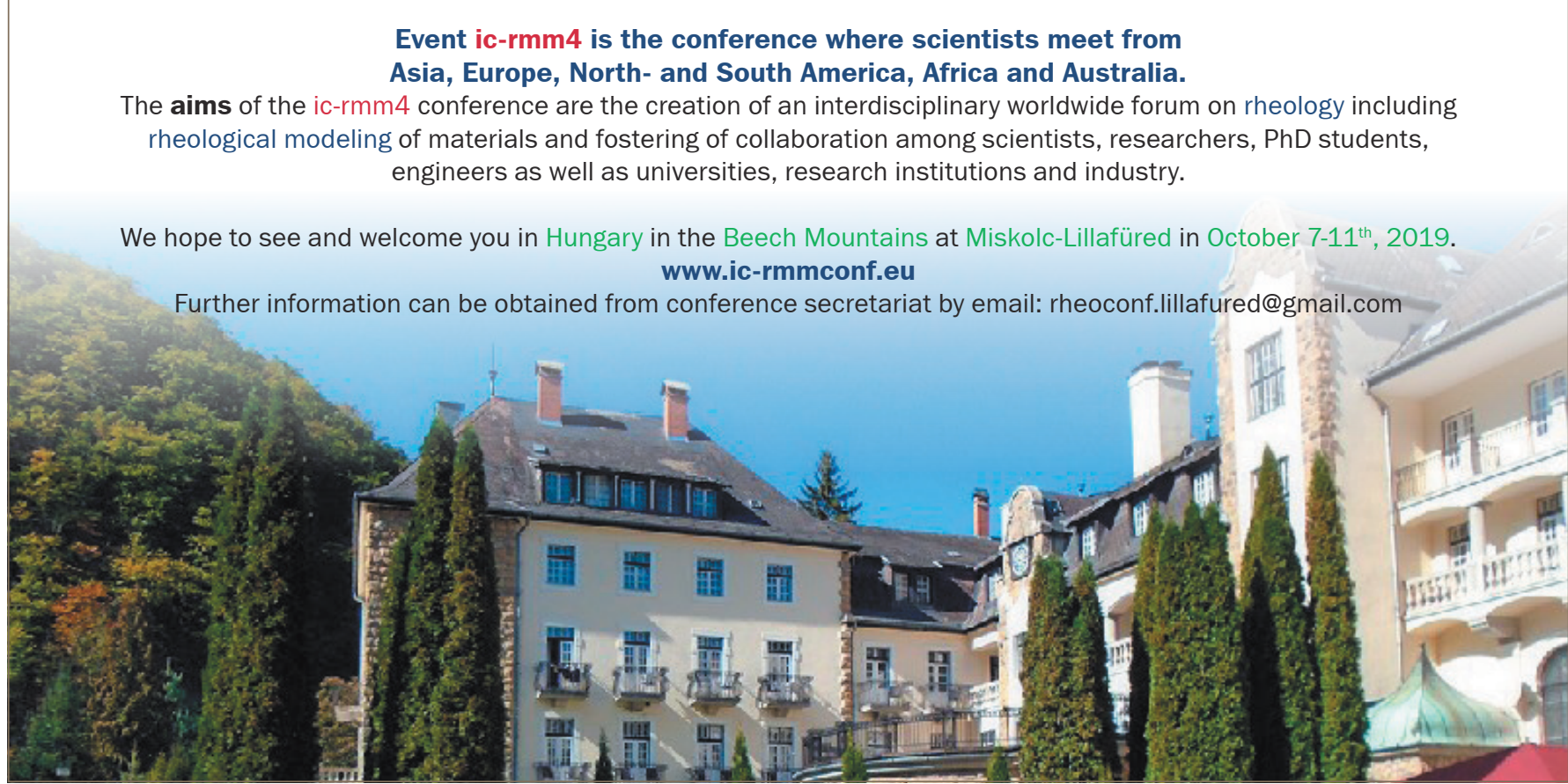

